\title{
Anthropogenic Signatures in the Context of Landscape Evolution: Evidence from Citanduy Watershed, Java, Indonesia
}

\author{
Mukhamad Ngainul Malawani ${ }^{1,2, *}$, Djati Mardiatno ${ }^{1,3}$, and Eko Haryono ${ }^{1}$ \\ ${ }^{1}$ Environmental Geography Department, Faculty of Geography, Universitas Gadjah Mada, Jl. Kaliurang, Yogyakarta 55281, Indonesia \\ ${ }^{2}$ Laboratoire de Géographie Physique, UMR 8591, CNRS, 1 Place Aristide Briand, 92195 Meudon, France \\ ${ }^{3}$ Centre for Disaster Study, Universitas Gadjah Mada, Jl. Mahoni, Bulaksumur C-16, Yogyakarta 55281, Indonesia \\ *Corresponding author: malawani@ugm.ac.id
}

KEYWORDS

Anthropocene

Anthropogenic

Landscape evolution

Segara Anakan

Sediment

\begin{abstract}
The impact of humans on landscapes may differ across regions because anthropogenic intervention on the respective landscapes occurs in different human-induced contexts. This study was designed to assess the human-induced landscape evolution of the Citanduy Watershed, Java, Indonesia, and determine its anthropogenic signatures. Several approaches were used, namely anthropogenic landscape identification, anthropogenic soil development, sediment analysis, and monitoring of changes to Segara Anakan lagoon at the mouth of the Citanduy Rier. Five types of anthropogenic landscapes were observed in the research area, from a slightly modified landscape to a fully anthropogenic landscape. The anthropogenic signature was also found in the sediment of the lagoon. Present and recent environmental evolution of the lagoon was reconstructed based on series changes in the lagoon area. This reconstruction was then linked to the governmental program and anthropogenic intervention to reveal the complexity of the human-induced landscape evolution. Anthropogenic phenomena were found to strongly influence the evolution of Segara Anakan lagoon, as recorded approximately through three phases of its evolution: 1) natural processes occurring continuously until 1960,2) human-induced landscape evolution, the boundary of which occurred in 1960-1980, and 3) the recent anthropogenic evolution that has existed since 1980.
\end{abstract}

(c) The Author(s) 2020. This article is distributed under a Creative Commons Attribution-ShareAlike 4.0 International license.

\section{INTRODUCTION}

The recent development of Holocene environmental evolution studies has shown how landscapes and environments change with any kind of marker or signature. Moreover, these kinds of studies have been of great interest to researchers investigating how humans play a role in environmental changes. Besides urban areas, humans have influenced environmental changes in remote areas, as recorded from diatoms and plant communities (Martel-Cea et al. 2016). On a regional scale, anthropegenic and climatic impacts on environmental changes can also be investigated based on a lake's sedimentary record of pollen (Calò et al. 2012). In coastal areas, human intervention has impacted the formation of coastal dunes, accelerating the distinctions of dunes (Sunarto et al. 2018). These studies underline that every change potentially records a type of signature, marker, or proxy.

Anthropogenic processes are related to Anthropocene signatures. Anthropogenic activities, such as plastic or litter deposits, may signal the start of the Anthropocene (Hoffmann and Reicherter 2014; Zalasiewicz and Williams 2014), which is indicated by rapid changes in the Earth's surface and atmospheric composition (Crutzen and Stoermer 2000). Many Anthropocene signatures related to the evolution of landscapes have been proposed, one of which is the presence of anthropogenic soil, namely anthrosol and technosol (Certini and Scalenghe 2011; Lewis and Maslin 2015). Another potential signature is the presence of fossils formed from crops (Lewis and Maslin 2015). This signature can be very useful for tracing the evolution of the landscape due to agricultural activities because agricultural practices are estimated to have dominated human activities more than any other practice (Hamilton 2015). Most of the landscape changes on Earth are now due to human activity. To determine these landscape changes, anthropogenic landscapes have been classified in terms of the rate of human intervention on Earth morphology (Csorba 2010).

Indonesia is a large archipelagic country that has undergone major development. This development has spread rapidly from rural to urban areas, and has the potential of leading to human-induced landscape evolution. The most populated island in Indonesia is Java, and home to a projected $56.57 \%$ of the Indonesian population (Statistics Indonesia 2018). Java, as the center of Indonesia's growth, has $45.54 \%$ of the total irrigated area from rice fields in Indonesia (Statistics Indonesia 2018). Multi-proxy evidence from stalagmite revealed that human-induced deforestation in Java started around 0.5 ka BP (Hartmann et al. 2013). Java is consequently considered to be one of the regions most impacted by anthropogenic pressure from agricultural practices, as well as the island with the highest potential for environmental changes compared with other islands in Indonesia. This study aimed to investigate the human impact 
on landscape evolution in Indonesia, in an area that is representative of Java, namely the Citanduy Watershed. This location was chosen because rapid environmental and landscape change is indicated, especially in the Segara Anakan lagoon at the mouth of the watershed. Citanduy River has high sedimentation rates, while high tides in the mouth of the river cause sediments to be left in the lagoon (Sarmili and Faturachman 2016). During the past 20 years, Segara Anakan lagoon has shrunk by 2000 hectares (Sukardi 2010). These landscape changes require an explanation, especially with respect to anthropogenic influences.

\section{ENVIRONMENTAL SETTING}

This research was conducted in the Citanduy Watershed, Java (Figure 1). The Citanduy Watershed has unique hydrological conditions because of its large transportation of sediment and various dynamic marine processes. During high tides, the sediment of the river, with an average concentration $0.2 \mathrm{~kg} / \mathrm{m}^{3}$, spreads out into the lagoon and are blocked by the tide (Balai Pantai 2016). This amount of sediment is not deposited into the ocean, instead remaining in Segara Anakan lagoon at the mouth of the river. The area of land cultivated by humans, either by intensive agriculture or settlements is 418,000 hectares, and represents more than $90 \%$ of the land use in the Citanduy Watershed. The most widespread land use is dry land farming along with bush and mixed gardens. This kind of land use is also common in the upper reaches of the watershed where intensive fertilization is used. Carbon in the soil has gradually increased due to the intensive use of organic fertilizer, which is the most common fertilizer in subsistence agriculture in Java (Haryono et al. 2016), as well as in the Citanduy Watershed.

With respect to the Citanduy Watershed, there are five administrative regions located in West and Central Java. Among of these, the largest is Tasikmalaya Regency with a population of 1,754,130 people. Banjar has the smallest population, with only 130,110 people (Statistics Indonesia 2020). Data from Statistics Indonesia show that the population growth in the Citanduy Watershed is classified as high, with an average annual growth index of 1.61. The high rate of growth causes some problems related to settlements. People began to move from urban to rural areas comparable to the surrounding areas of the Segara Anakan lagoon in between 1970 and 1980. People built new villages and settlements and then developed agricultural plots such as rice fields. Rice fields subsequently became the most im-

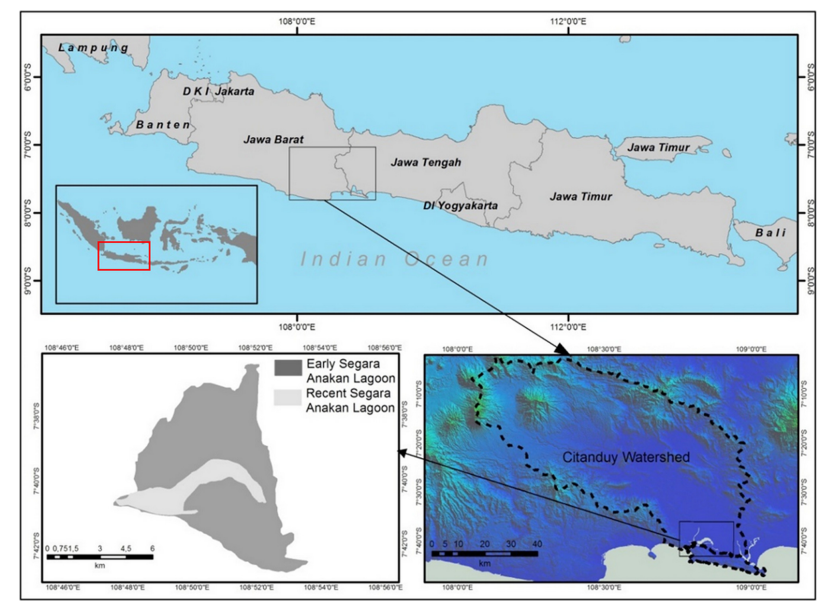

FIGURE 1. Study area and current Segara Anakan water cover. portant land use around the lagoon area of Segara Anakan (Ardli and Wolff 2009). This area also has susceptibility to tsunamis, especially in the areas near Cilacap Regency, located in the southern part of the study area. Based on a worst-case tsunami scenario, the tsunami wave can easily reach the Segara Anakan lagoon via the Durian River in the southeastern part of the study area (Mardiatno et al. 2009).

\section{METHODS}

This study investigated the initiation of human impact on the landscape through three components. The first was general landform identification using SRTM at a resolution of 1 arc-second $(\sim 30 \mathrm{~m})$ and Landsat imagery (acquisition in 2016) data to identify the anthropogenic landscape. Terrestrial surveys were then conducted to verify the satellite image interpretation (Figure 2). Data collected in field included landscape morphography and morphometry for verifying the rate of human intervention. The landscape was then classified into five categories based on the level of human intervention (Csorba 2010). The second component was the tracking of anthropogenic signatures. Four signatures were studied using primary data together with field surveys and observations: 1) anthropogenic landscape, 2) anthropogenic soils, 3) litter deposits in the sediment, and 4) accelerated landscape change. Secondary data were also used to investigate accelerated environmental and landscape changes, especially in the mouth of the watershed, i.e. Segara Anakan lagoon. In this investigation, we use data from Lukas (2014), Sukardi (2010), the appendix of Minister of Public Works Decree No. 483 of 2013 (KPUPR 2013), and recent imagery from Landsat. Most of the data on lagoon dynamics are based on imagery interpretation and ancient map re-delineation. Sediment samples from boreholes were sent to the National Nuclear Energy Agency for dating $\left({ }^{14} \mathrm{C}\right)$ of the selected sediment layer. The final component was reconstructing the landscape and environmental changes in a schematic phase. This reconstruction was conducted by linking between the anthropogenic signature and anthropogenic practices or governmental programs.

\section{RESULTS}

\subsection{Anthropogenic landscape}

The Citanduy Watershed now has a completely anthropogenic landscape if investigated in detailed-scale. Previously, the original landscape was completely natural with-

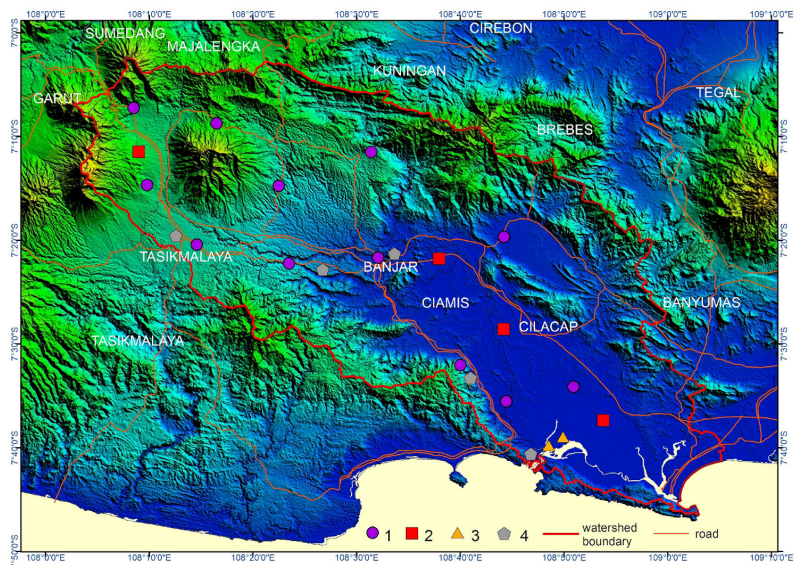

FIGURE 2. Location of terrestrial identifications in the Citanduy Watershed. Identifications conducted: (1) morphology and morphometry; (2) soil identification; (3) borehole; (4) interviews with local people. 
out any human intervention. The upstream and mountainous areas of Citanduy are still classified as a natural landscape in this study. The second category (level) is a slightly modified landscape, as found in rural farming areas. Agricultural areas at this level support low intensity agriculture and remain dominated by natural processes. The Citanduy Watershed has large agricultural areas on the alluvial plains, located on undulating and flat areas (Figure 3). The third category is a semi-modified landscape. This landscape is primarily caused by human activities related to intensive agriculture. This landscape is characterized by a change in slope. Another category is the semi-natural landscape that can be found in oxbow lakes or in abandoned rivers. Most of these sites have been transformed through human activity into aquaculture and fishing fields.

The next category is a landscape that has changed from its original, natural conditions. Most of this landscape was originally sloped hills that have since been converted to flat areas for development purposes. The last and highest level due to human intervention is the anthropogenic landscape. This landscape is found in urban areas such as Banjar, Tasikmalaya, and Ciamis and is characterized by vertical growth. Accelerated morphological changes for residential needs were quite substantial in the study area (Figure 4). Another morphological change is the result of mining activities due to the large mineral potential found in the Citanduy Watershed; however, agriculture has a larger affect than mining. Several human interventions that directly induced landscape evolution in the Citanduy Watershed, in order of strongest to weakest, are agriculture (including aquaculture), settlement, mining, and tourism.

\subsection{Anthropogenic soils}

The location samples of anthropogenic soils were selected based on the morphological characteristic (Figure 3); however the anthropogenic soil sample for mountainous morphology is missing. The anthropogenic soil was found in a selected area dominated by human activity, mostly

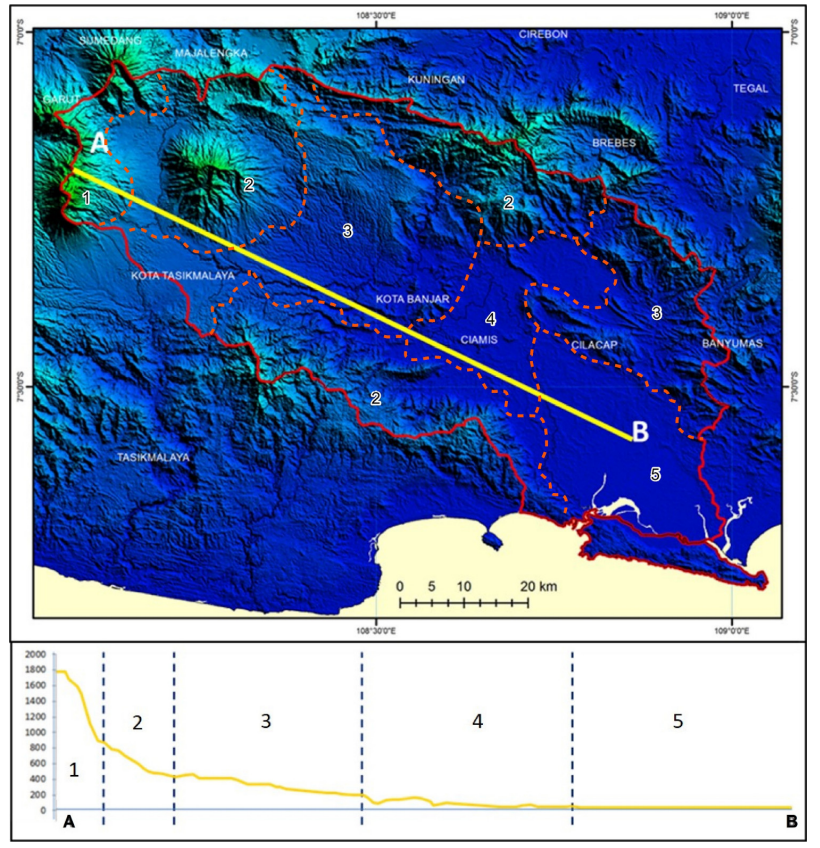

FIGURE 3. SRTM imagery of the Citanduy Watershed and elevation profile from upstream to downstream. The morphology can be divided into five morphological classes: (1) steep mountainous; (2) mountainous; (3) hilly; (4) undulating; and (5) flat. stemming from intense agricultural activities. These soils formed from a sediment layer of regosol, which experienced pedogenesis and geogenesis through human agents. The anthropogenic soil in this study was investigated based on two soil types from the World Reference Base for Soil Resources (WRB), technosol and anthrosol (FAO 2006). Technosol was not found in the study area, because its diagnostic horizon is difficult to find. Therefore, the anthropogenic soil was investigated only through anthrosol. The anthrosol found in study area formed in several diagnostic horizons, namely plaggic, irragric, anthraquic, and hydragric (Figure 5). Furthermore, the soil survey was conducted at the regional scale, while the identified physical characteristics were limited to field observations.

The results of soil identification showed that the four diagnostic horizons could be found in different regions. The anthraquic horizon was found in upstream areas with a thickness of more than $20 \mathrm{~cm}$. This indicates that the agricultural fields in the upstream are quite thick. In the upstream, soil consisted of a dark-brown colored layer with 7.5 YR on the Munsell color chart. The development of anthropogenic soil in the middle-stream was characterized by the presence of an irragric and plaggic diagnostic horizon. These two diagnostic horizons were almost the same, with the difference between the two being the clay content. Plaggic has fewer clays so it tends to be loam textured. Anthropogenic soil in the downstream was characterized by a hydragric horizon, as reflected by the often inundated land. This soil horizon was found in agricultural areas, which are quite intensive with a large frequency of flooding every year. This horizon was gray with a value of 2.5 YR on the Munsell color chart.

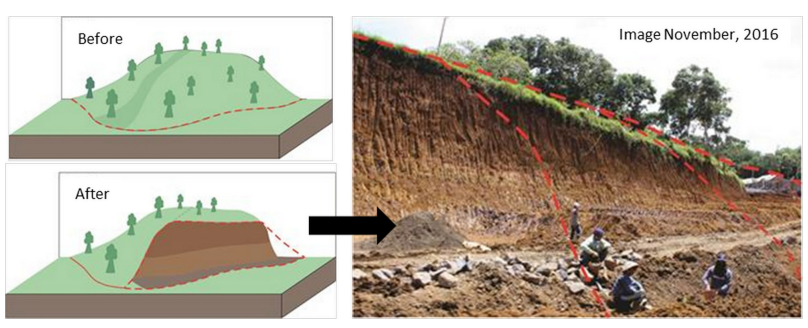

FIGURE 4. Accelerated morphological changes caused by human intervention. Slope cut for residential building in the middle part of the watershed.

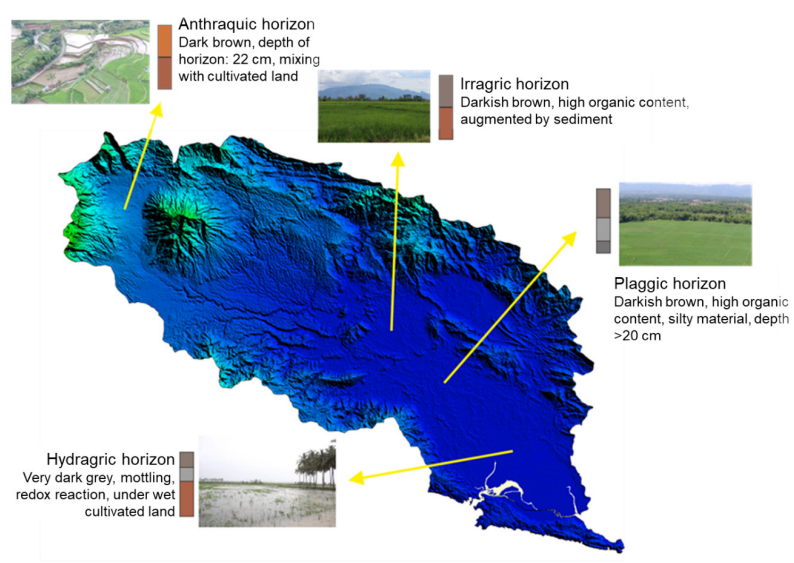

FIGURE 5. Anthropogenic soil distribution in the study area. From the upstream to downstream, four diagnostic horizons were found from anthrosols. 


\subsection{Historical lagoon changes}

Historical lagoon changes were recorded based on the changes of water coverage in the Segara Anakan lagoon. Based on various collected data, morphological lagoon changes are divided into three periods. The first period comprises the continuous natural evolution until 1960. Morphological changes of this period indicated only small changes. Land aggradation during this period averaged 22 hectares/year. During the second period, the rate of aggradation increased. The second period occurred in the years 1960-1980. The land aggradation rate recorded at this time was 90 hectares/year. During the third period, which began in 1980, land aggradation increased to 130 hectares/year. More dramatic changes occurred after 2000. Many forms of environmental management applied in the Citanduy Watershed contributed to a serious decrease in sediment transportation. During this period, morphological changes in the Segara Anakan lagoon became very slow. Not much water surface aggraded to become land mass. Based on our interpretation of 2016 Landsat imagery, the area of Segara Anakan is now 485 hectares compared compared with $>6,000$ hectares in early 1900 . Land aggradation started from fringe areas, and gradually proceeded to the center area of the lagoon (Figure 6). Because of its rapid changes, Segara Anakan lagoon is the best area for monitoring environment and landscape evolution due to human activities.

\subsection{Anthropogenic signatures}

Four signatures recorded the evidence of human disturbance on the landscape in the study area. The first was the existence of the anthropogenic landscape. The levels of anthropogenic landscape found in the study area ranged from natural to the highest degree of anthropogenic influence. All five levels of human intervention on the landscape has occurred in the Citanduy Watershed. The second signature was anthropogenic soils, which were found in agricultural areas. Some anthropogenic horizons were classified according to the WRB, resulting in what were found to be plaggic, irragric, anthraquic, and hydragric soils. In addition, morphological changes in the Segara Anakan lagoon at the mouth of the Citanduy Watershed can be used as an indicator of the evolution from a natural to human-induced land-
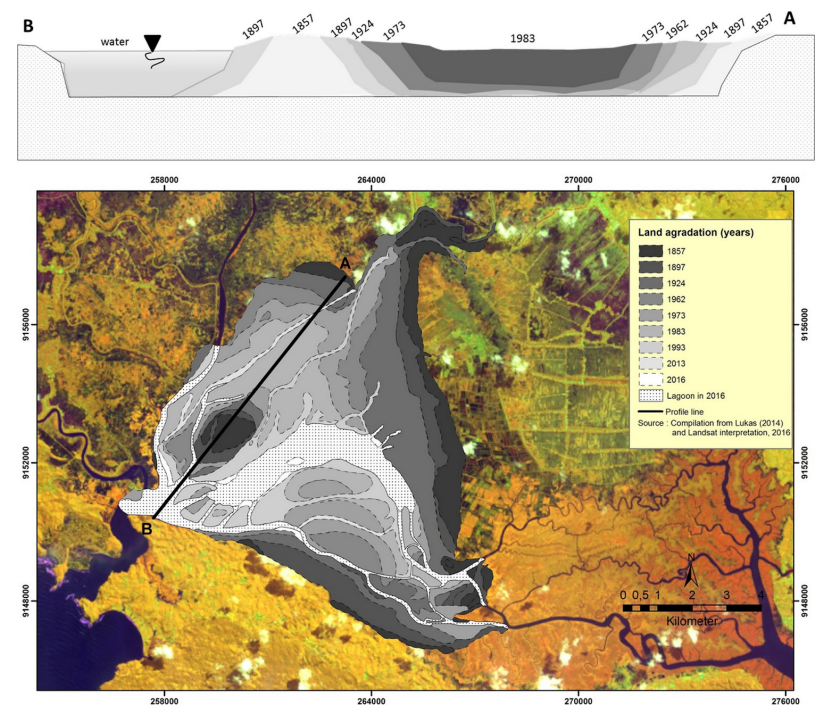

FIGURE 6. Morphological lagoon changes of Segara Anakan. Water depth in this reconstruction is not scaled. scape. The morphological changes in the Segara Anakan lagoon during the century prior to 1960 were nearly equivalent to those of the 30-year period from 1960 to 1990. This suggests that approximately in 1960 an acceleration of sedimentation occurred in the lagoon.

Some plastics (litter deposits) in sediments were recorded in Segara Anakan lagoon deposits. These plastics can be used as a human impact marker and may be used as an indicator of the acceleration of the sedimentation rate. Plastic material produced in 2006-2007 was found at a depth of $100 \mathrm{~cm}$ (Figure 7). Based on normal conditions, it can be calculated that the rate of sedimentation layered in the Segara Anakan lagoon is $\pm 10 \mathrm{~cm} /$ year. Another borehole was bored in order to identify the lithological type in the lagoon sediment. Based on four sediment layers found in the borehole, radiocarbon dating was conducted on the fourth layer due to its organic content. The dating results showed that the fourth layer formed in 1977 BP (un-cal.), indicating that these sediments were formed during the Holocene. In the fourth layer, marine deposits were found that turned into fluvial deposits, as indicated by landscape changes, namely the changes of a grain texture of clay into sandy. This layer could be a representation of the evolution from the natural to the human-induced landscape, as indicated by the first and second layers. Fluvial processes became more dominant and characterized by the amount of sand. Neither of these layers could be analyzed by radiocarbon dating methods due to limited organic content.

\section{DISCUSSION}

\subsection{Landscape evolution}

The early evolution of the landscape and environment in the study area was identified to occur before 1960. This period is characterized by the rate of landscape changes that occurred prior to 1960. Sedimentation in Segara Anakan at this time was apparently based on natural processes. Human intervention was absent and morphological changes were very slow. Marine processes are more dominant in Segara Anakan lagoon. Previous research showed that Segara Anakan had an average depth of $2.7 \mathrm{~m}$ (Irwansyah et al. 2003), but now the average depth of Segara Anakan

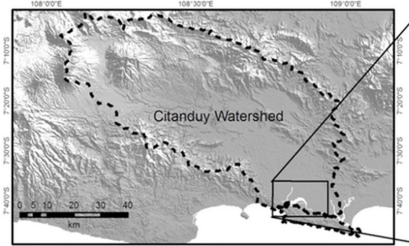

Borehole A





Borehole B



FIGURE 7. Sediment boreholes of the Segara Anakan lagoon. Borehole A does not indicate a distinct sediment layer, whereas borehole $B$ has four different sediment types. 
TABLE 1. Early evolution (in hectares) of Segara Anakan lagoon.

\begin{tabular}{cccc}
\hline \multicolumn{3}{c}{ Year } \\
\hline 1887 & 1903 & 1924 & 1939 \\
\hline- & $7500^{1}$ & - & $6500^{1}$ \\
$5901^{2}$ & - & $4564^{2}$ & - \\
- & $6500^{3}$ & - & $6000^{3}$ \\
\hline
\end{tabular}

${ }^{1}$ KPUPR 2013; ${ }^{2}$ Lukas (2014); ${ }^{3}$ Sukardi (2010)

lagoon is less than $1.5 \mathrm{~m}$. Various sources of data that mention the area of the lagoon are shown in Table 1.

The next evolution was the transition to an anthropogenic landscape, inferred from the surface area of Segara Anakan's water body (Figure 8). Almost 1000 hectares of land aggradation occurred within ten years. Sediment input to the lagoon tended to increase faster compared with the previous evolution. Anthropogenic practices along the upper stream had great influence on the rate of sedimentation. Heavy agricultural practices triggered very high sedimentation in the catchment area of Segara Anakan. Agricultural areas have a strong influence on environmental carrying capacity, wherein larger agricultural areas have a tendency to lower environmental carrying capacity (Muta'ali 2011). As a result, the Citanduy catchment area became the first watershed in Indonesia to utilize an Integrated Watershed Management Program (Nugroho 2003).

The recent phase of landscape evolution was classified as anthropogenic evolution. Morphological changes in Segara Anakan after 1980 occurred slowly because of improved watershed management by the Indonesian government (Table 2). There has been no significant change in the water surface area of Segara Anakan lagoon. The environmental practice program to reduce sedimentation rates can be considered a success for the government. Among these practices are the Cimeneng canal, which distributes sediment directly to the sea and dredging of sediment in the lagoon. In addition, the government worked to save the environmental and ecological functions of Segara Anakan lagoon. If there was no effort to maintain the sedimentation, the lagoon would likely develop into land, as Di Rita et al. (2011) found that lagoons progressively turn into grassland when impacted by sediment discharge.

\subsection{Transition of anthropogenic landscape}

The start of the anthropogenic era in the study area was first indicated by the existence of an anthropogenic land-

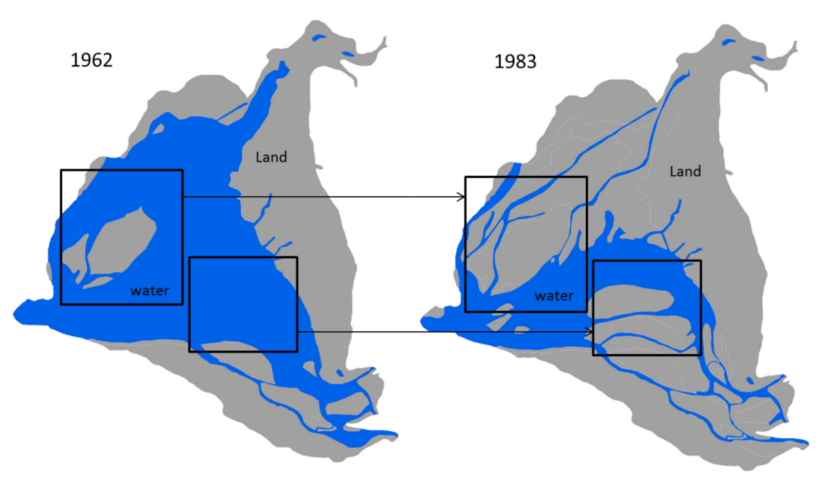

FIGURE 8. Water surface changes in Segara Anakan lagoon at the natural to anthropogenic landscape transition.
TABLE 2. Recent evolution (in hectares) of Segara Anakan.

\begin{tabular}{ccccc}
\hline \multicolumn{5}{c}{ Year } \\
\hline 1983 & 1992 & 1993 & 2000 & 2016 \\
\hline- & $1800^{1}$ & - & $800^{1}$ & - \\
$1922^{2}$ & - & $1303^{2}$ & - & - \\
$3200^{3}$ & $2000^{3}$ & - & $1000^{3}$ & - \\
- & - & - & - & $485^{4}$ \\
\hline
\end{tabular}

${ }^{1}$ KPUPR 2013; ${ }^{2}$ Lukas (2014); ${ }^{3}$ Sukardi (2010); ${ }^{4}$ Landsat

scape. Human interaction with it created an anthropogenic landscape that can be described in three ways: 1) comparing natural processes and anthropogenic processes, 2) integrating various data such as spatial data or remote sensing data, and 3) expanding the scale of the analysis from local to regional (Harden et al. 2014). These methods have been applied in this study for identifying the anthropogenic landscape. Anthropogenic landscapes have been documented with various types of anthropogenic practices: settlements, mining activities, tourism, and agricultural practices (Szabó et al. 2010). Interaction between humans and landscapes caused wide morphological changes and increased erosion rates in the study area. Anthropogenic practices in the study area triggered the formation of anthropogenic soils, mostly through intensive farming areas. It is important to note that in this study the anthropogenic soil was investigated just in the regional scale, not with a detailed soils survey. A similar method of soil identification for anthropogenic signatures was conducted in Australia by Fergusson (2017). This identification of anthropogenic soils is useful for preliminary studies of the Anthropocene (Stinchcomb et al. 2013). The various human practices and interventions associated with the landscape in the study area has a very close connection to the formation of the anthropogenic signatures. Figure 9 shows the connection between anthropogenic practices and landscape evolution.

Research on forested regions in Java mention that from 1950 to the present day, globalization and industrialization caused massive deforestation and changed heterogeneous forests into areas with dry land farming and mixed gardens (Faida et al. 2011). Strong anthropogenic intervention on natural systems have also been recorded on speleothems. Anthropogenic and natural systems can be distinguished based on multi-proxy evidence in from the speleothem of Bribin Cave in Java, which showed dramatic degradation caused by cultivation and deforestation (Hartmann et al.

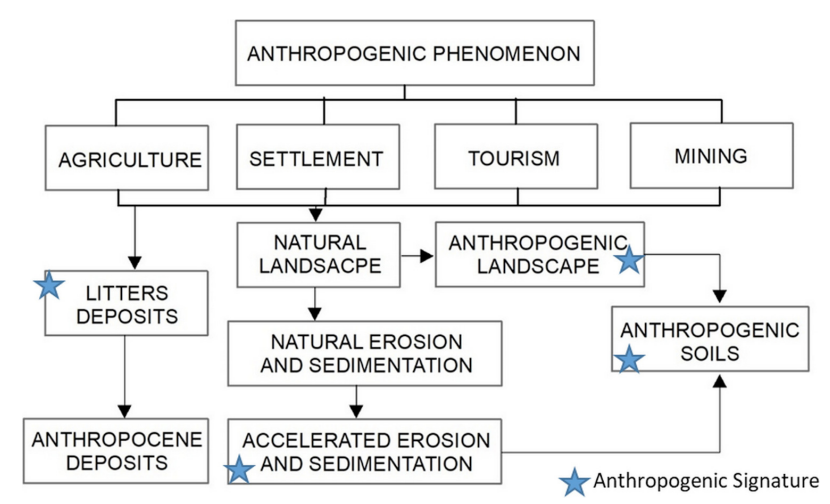

FIGURE 9. Connection between anthropogenic practices and the existence of the anthropogenic signatures in the study area. 
2013). As such, it can be observed that the development of anthropogenic phenomena in Java was triggered by the growth of its population. The demographic explosion recently became a severe problem in urban areas, spurring the government to launch transmigration and agricultural intensification programs to address it. However, these programs contributed to environmental changes, such as accelerated rates of erosion. This problem was followed by accelerated rates of sedimentation, as found in Segara Anakan lagoon. The Citanduy watershed became the most popular area for the agricultural intensification program and was marked by a specific rice commodity called the Citanduy paddy (Panuju et al. 2013). The series of potential changes from the natural to anthropogenic landscape in the study area are shown schematically in Figure 10.

Compared with other scenarios, the human impact on landscape evolution can also divided into three sequences (Migoń and Latocha 2018), albeit with different terms given to each phase, i.e. increased human impact, decreased human impact, and continued human impact. This research is very useful for future research on the Anthropocene in Indonesia. Further enhancement, such as the number of sediment boreholes used to describe the anthropogenic stratigraphy for supporting the Global Boundary Stratotype Section and Point for the Anthropocene epoch, is still necessary. Previous research has shown that the Anthropocene in North America potentially started when Europeans arrived in the $17^{\text {th }}$ century (Jalowska et al. 2015). Based on our findings, the Anthropocene in Indonesia likely occurred later than in North American or European countries. However, at present, the start of the Anthropocene remains uncertain, especially in Indonesia. It will be interesting to observe additional research in Indonesia that helps to define the Anthropocene through various approaches.

\section{CONCLUSIONS}

In the Citanduy Watershed, humans have triggered accelerated erosion and accelerated landscape changes, mostly due to agricultural practices. Various anthropogenic signatures have been discovered and proved that a transition from natural to anthropogenic landscape has occurred. Investigation on the watershed and lagoon system found that landscape evolution can be explained in sequential series changes. The landscape transition in the study area occurred gradually from 1960 to 1980. In every phase of its evolution, we found that it was marked by anthropogenic signatures. We assume that every landscape evolution accelerated by humans most likely left traces of humans or anthropogenic signatures within. However, this period of the transition may differ in other islands of Indonesia because of different human-induced contexts. The same is true of other countries and continents. In addition, the evidence of anthropogenic phenomena presented in this article is useful for preliminary research supporting the proposal of the Anthropocene epoch tipping point.

\section{ACKNOWLEDGMENTS}

This paper was part of the first author's master's thesis. We are very grateful to our other colleagues and reviewers for their constructive comments. Thanks for Cahyo N.R. Nugroho from Balai Pantai and Oktarina Purbawarti from BBWS Citanduy for the discussion of sedimentation rate in Segara Anakan lagoon. Special thanks also to Prof. Sunarto. For B. Nursalim and Al-Muqtasidah, thanks for the encouragement during writing process.

\section{AUTHORS' CONTRIBUTIONS}

MNM, DM, and EH designed the study. The manuscript was written by MNM with the contribution of DM and EH. Field work was conducted by MNM. All of the authors contributed in data analysis.

\section{COMPETING INTERESTS}

The authors declare no competing interests.

\section{REFERENCES}

Ardli ER, Wolff M. 2009. Land use and land cover change affecting habitat distribution in the Segara Anakan la-

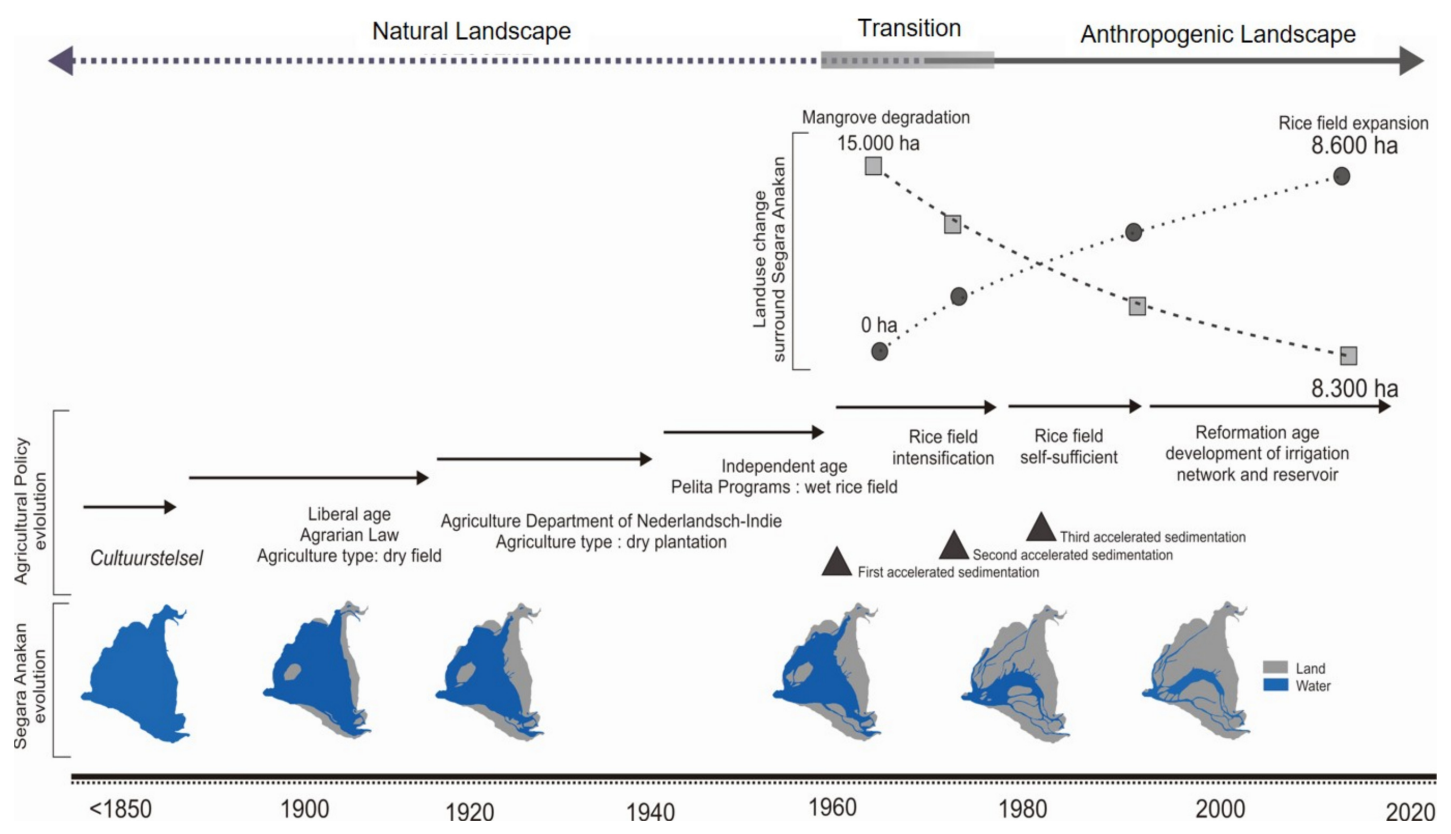

FIGURE 10. Reconstruction of sequential evolution from the natural to anthropogenic landscape, compiled from Ardli and Wolff (2009), Irwansyah et al. (2003), Panuju et al. (2013), and Sukardi (2010). 
goon, Java, Indonesia. Reg Environ. 9(4):235-243. doi: 10.1007/s10113-008-0072-6.

Balai Pantai. 2016. Pemodelan numerik Segara Anakan [Numeric modeling of Segara Anakan]. Buleleng: Balai Pantai.

Calò C, Henne PD, Curry B, Magny M, Vescovi E, La Mantia T, Pasta S, Vannière B, Tinner W. 2012. Spatio-temporal patterns of Holocene environmental change in southern Sicily. Palaeogeogr Palaeoclimatol Palaeoecol. 323325:110-122. doi:10.1016/j.palaeo.2012.01.038.

Certini G, Scalenghe R. 2011. Anthropogenic soils are the golden spikes for the Anthropocene. Holocene. 21(8):1269-1274. doi:10.1177/0959683611408454.

Crutzen PJ, Stoermer EF. 2000. The Anthropocene. Global Change Magazine. 41:17-18.

Csorba P. 2010. Anthropogenic geomorphology and landscape ecology. In: Szabó J, Dávid L, Lóczy D, editors. Anthropogenic geomorphology: a guide to man-made landforms. Dordrecht: Springer. p. 39-52. doi:10.1007/ 978-90-481-3058-0_4.

Di Rita F, Simone O, Caldara M, Gehrels WR, Magri D. 2011. Holocene environmental changes in the coastal Tavoliere Plain (Apulia, southern Italy): a multiproxy approach. Palaeogeogr Palaeoclimatol Palaeoecol. 310:139-151.

Faida LRW, Sutikno S, Fandeli C, Sunarto S. 2011. Rekonstruksi hutan purba di Kawasan Karst Gunungsewu dalam periode sejarah manusia [Reconstruction of ancient forests in the Gunungsewu Karst Area in the period of human history]. Jurnal Ilmu Kehutanan. 5(2):7990. doi:10.22146/jik.1852.

[FAO] Food and Agriculture Organization. 2006. World reference base for soil resources 2006: a framework for international classification, correlation and communication. Rome: FAO.

Fergusson L. 2017. Anthrosols and technosols: the anthropogenic signature of contaminated soils and sediments in Australia. Water Air Soil Pollut. 228(8):1-14. doi:10.1007/s11270-017-3460-z.

Hamilton C. 2015. Getting the Anthropocene so wrong. Anthropocene Rev. 2(2):102-107. doi:10.1177/2053019615 584974.

Harden CP, Chin A, English MR, Fu R, Galvin KA, Gerlak AK, McDowell PF, McNamara DE, Peterson JM, Poff NL, Rosa EA, Solecki WD, Wohl EE. 2014. Understanding human-landscape interactions in the "Anthropocene". Environ Manage. 53(1):4-13. doi:10.1007/s00267-013-0 082-0.

Hartmann A, Eiche E, Neumann T, Fohlmeister J, SchröderRitzrau A, Mangini A, Haryono E. 2013. Multi-proxy evidence for human-induced deforestation and cultivation from a late Holocene stalagmite from middle java, Indonesia. Chem Geol. 357:8-17. doi:10.1016/j.chemge o.2013.08.026.

Haryono E, Danardono, Mulatsih S, Putro ST, Adji TN. 2016. The nature of carbon flux in Gunungsewu karst, JavaIndonesia. Acta Carsologica. 45(2):173-185. doi:10.398 6/ac.v45i2.4541.

Hoffmann G, Reicherter K. 2014. Reconstructing Anthropocene extreme flood events by using litter deposits. Global Planet Change. 122:23-28. doi:10.1016/j.glopla cha.2014.07.012.

Irwansyah E, Soesilo I, Kusratmoko E. 2003. Morphodynamic of lagoon Segara Anakan, Cilacap, Central Java. Jurnal Geografi:1-11.

Jalowska AM, Rodriguez AB, McKee BA. 2015. Responses of the Roanoke Bayhead Delta to variations in sea level rise and sediment supply during the Holocene and Anthropocene. Anthropocene. 9:41-55. doi:10.1016/j.ance ne.2015.05.002.

[KPUPR] Ministry of Public Works and Public Housing of Indonesia. 2013. Minister of Public Works Decree No. 483/KPTS/M/2013. Pola pengelolaan sumber daya air wilayah sungai Citanduy [Planning of water resource management in Citanduy watershed]. Jakarta: Ministry of Public Works and Public Housing of Indonesia.

Lewis SL, Maslin MA. 2015. Defining the Anthropocene. Nature. 519(7542):171-180. doi:10.1038/nature14258.

Lukas MC. 2014. Cartographic reconstruction of historical environmental change. Cartogr Perspect. 2014(78):5-24. doi:10.14714/CP78.1218.

Mardiatno D, Marfai M, Sartohadi J. 2009. Multi-risk of disaster in Cilacap City. Proceeding of the International Conference on Coastal Environment and Management. p. 6-14.

Martel-Cea A, Maldonado A, Grosjean M, Alvial I, de Jong R, Fritz SC, von Gunten L. 2016. Late Holocene environmental changes as recorded in the sediments of high Andean Laguna Chepical, Central Chile $\left(32^{\circ} \mathrm{S} ; 3050 \mathrm{~m}\right.$ a.s.l.). Palaeogeogr Palaeoclimatol Palaeoecol. 461:4454. doi:10.1016/j.palaeo.2016.08.003.

Migoń P, Latocha A. 2018. Human impact and geomorphic change through time in the Sudetes, Central Europe. Quatern Int. 470:194-206. doi:10.1016/j.quaint.2018.01 .038 .

Muta'ali L. 2011. Environmental carrying capacity based on spatial planning. Indones J Geogr. 43(2):142-155. doi: 10.22146/IJG.2382.

Nugroho SP. 2003. Pergeseran kebijakan dan paradigma baru dalam pengelolaan daerah aliran sungai di Indonesia [New policy and paradigm shift in watershed management in Indonesia]. Jurnal Teknologi Lingkungan. 4(3):136-142. doi:10.29122/JTL.V4I3.283.

Panuju DR, Mizuno K, Trisasongko BH. 2013. The dynamics of rice production in Indonesia 1961-2009. J Saudi Soc Agric Sci. 12(1):27-37. doi:10.1016/j.jssas.2012.05.002.

Sarmili L, Faturachman F. 2016. Indikasi pembentukan delta pasang surut ebb di mulut outlet Segara Anakan Bagian Barat, Teluk Pangandaran, Jawa Barat [Indication of the formation an ebb tidal delta in the western part of Segara Anakan outlet, Pangandaran Bay, West Java]. Jurnal Geologi Kelautan. 2(1):11-17. doi:10.32693/jgk.2.1.2 004.104.

Statistics Indonesia. 2018. Statistical Yearbook of Indonesia 2018. Jakarta: Statistics Indonesia. https://www.bps. go.id/publication/2018/07/03/5a963clea9b0fed64 97d0845/statistik-indonesia-2018.html.

Statistics Indonesia. 2020. Jawa Barat Province in Figures 2020. Bandung: Statistics Indonesia. https://jabar.bp s.go.id/publication/2020/02/28/84b608d4cfe5274 e6e79deec/provinsi-jawa-barat-dalam-angka-2020 --penyediaan-data-untuk-perencanaan-pembanguna n.html.

Stinchcomb GE, Stewart RM, Messner TC, Nordt LC, Driese SG, Allen PM. 2013. Using event stratigraphy to map the Anthropocene - an example from the historic coal mining region in eastern Pennsylvania, USA. Anthropocene. 2:42-50. doi:10.1016/j.ancene.2013.06.001.

Sukardi S. 2010. Permasalahan kawasan Segara Anakan [Problems in the Segara Anakan area]. Perencanaan Pembangunan. 16(2):2-10.

Sunarto, Malawani MN, Fatchurohman H, Cahyadi A. 
2018. Identification of landscape disturbance in the parangtritis sand dune area for sustainable environment. IOP Conf Ser: Earth Environ Sci. 179:012030. doi:10.1088/1755-1315/179/1/012030.

Szabó J, Dávid L, Lóczy D, editors. 2010. Anthropogenic geomorphology: a guide to man-made landforms. Dor- drecht: Springer. doi:10.1007/978-90-481-3058-0. Zalasiewicz J, Williams M. 2014. The anthropocene: a comparison with the Ordovician-Silurian boundary. Rend Fis Acc Lincei. 25(1):5-12. doi:10.1007/s12210-013-026 $5-\mathrm{x}$. 